\title{
The Human UGT2B7 Nanodisc
}

\author{
lan Cook, Anna B. Asenjo, Hernando Sosa, and Thomas S. Leyh \\ Departments of Microbiology and Immunology (I.C., T.S.L.) and Physiology and Biophysics (A.B.A., H.S.), \\ Albert Einstein College of Medicine, New York City, New York
}

Received November 14, 2019; accepted December 30, 2019

\begin{abstract}
The 20 uridine diphosphate glycosyl-transferases (UGTs) encoded in the human genome form an essential homeostatic network of overlapping catalytic functions that surveil and regulate the activity and clearance of scores of small molecule metabolites. Biochemical and biophysical UGT studies have been hampered by the inability to purify these membrane-bound proteins. Here, using cell-free expression and nanodisc technology, we assemble and purify to homogeneity the first UGT nanodisc-the human UGT2B7•nanodisc. The complex is readily isolated in milligram quantities. It is stable and its initial-rate parameters are identical within error to those associated with UGT2B7 in microsomal preparations (i.e., Supersomes). The high purity of the nanodisc preparation simplifies UGT assays, which allows complexities traditionally associated with microsomal assays (latency and the albumin effect) to be circumvented. Each
\end{abstract}

nanodisc is shown to harbor a single UGT2B7 monomer. The methods described herein should be widely applicable to UGTs, and these findings are expected to set the stage for experimentalists to more freely explore the structure, function, and biology of this important area of phase II metabolism.

\section{SIGNIFICANCE STATEMENT}

Lack of access to pure, catalytically competent human uridine diphosphate glucuronosyl-transferases (UGTs) has long been an impediment to biochemical and biophysical studies of this diseaserelevant enzyme family. Here, we demonstrate this barrier can be removed using nanodisc technology-a human UGT2B7•nanodisc is assembled, purified to homogeneity, and shown to have activity comparable to microsomal UGT2B7.

\section{Introduction}

Collectively, the 20 uridine diphosphate glucuronosyl-transferase (UGT) isoforms encoded in the human genome regulate the activity, solubility, transport, and clearance of scores of xenobiotics and endogenous metabolites. In so doing, they defend against the toxicities of environmental chemicals and maintain the homeostatic balance of numerous metabolic processes. UGTs regulate the receptor binding and terminal half-lives of steroids (Hum et al., 1999; Sten et al., 2009), thyroid hormones (Visser et al., 1993; Richardson and Klaassen, 2010), and neurotransmitters (Antonio et al., 2003); they limit volatility and hence "shape" olfaction (Lazard et al., 1991; Jedlitschky et al., 1999; Sneitz et al., 2009); glucuronidation potently activates morphine and controls its blood-brain-barrier transport (Pasternak et al., 1987; Francés et al., 1990; Osborne et al., 1990; Wu et al., 1997; Zelcer et al., 2005); finally, coincident upregulation of UGTs and multiple-drug-resistance transporters confers chemo-resistance in cancer cells (Bock et al., 2000; Meijerman et al., 2008; Tolson and Wang, 2010). Despite their importance, the fundamental structure/function information needed to predict, interpret, and control the molecular behavior of UGTs is largely absent from the field due primarily to the challenges associated with purifying these membrane-bound enzymes.

Supported by the National Institutes of Health Grants R01GM113164 (H.S.), R01GM121849 (T.S.L.), and R35GM127144 (T.S.L.).

https://doi.org/10.1124/dmd.119.089946.
The catalytic domains of UGTs are tethered to the luminal side of the smooth endoplasmic reticulum by a single-pass, C-terminal trans-membrane helix and cannot be separated from the membrane without significant loss of activity (Mackenzie, 1987; Meech and Mackenzie, 1997, 1998; Kurkela et al., 2003). Consequently, in vitro UGT experiments are typically performed using microsomes (membraneous preparations isolated from cells by differential centrifugation) and hepatocytes. Although such systems have led to extensive insights into UGT selectivity, tissue expression, and metabolism (Rowland et al., 2013; Oda et al., 2015; Lv et al., 2019; Meech et al., 2019), they do not provide opportunity to study the pure enzyme. Nanodiscs are widely used in the purification of membrane-bound proteins. These lipid discs are ringed by amphipathic membrane scaffolding proteins (MSPs), and their dimensions (10-16 nm) are well suited to incorporating single- and multiple-pass membrane proteins (Civjan et al., 2003; Denisov et al., 2004). Here, using cell-free expression techniques, we assemble, purify, and characterize a nanodisc that harbors the human UGT2B7-the isoform that glucuronidates numerous endogenous steroids (Cheng et al., 1998; Coffman et al., 1998; Girard et al., 2003) and plays pivotal roles in morphine activation (Stone et al., 2003) and the inactivation of AZT (Barbier et al., 2000). We anticipate that the cell-free nanodisc technology will be applicable to numerous UGT isoforms and will provide experimentalists with ready access to a wide variety of pure, active UGTs nanodiscs.

ABBREVIATIONS: AZT, azidothymidine; GSH, glutathione; HIS, histidine; HPLC, High Pressure Liquid Chromatography; KCl, potassium chloride; $\mathrm{KOH}$, potassium hydroxide; $\mathrm{LiCl}$, lithium chloride; $\mathrm{MBP}$, maltose binding proteinr; NTP, ribonuceloside triphosphate; 4-MU, 4-methylumbelliferone; BSA, bovine serum albumin; DTT, dithiothreitol; GST, glutathione S-transferase; MSP, membrane scaffold protein; MWCO, molecular weight cut off; PMSF, phenylmethylsulfonyl fluoride; POPC, 1-palmitoyl-2-oleoyl-sn-glycero-3-phosphocholine; SULT, sulfotransferase; TCE, 2,2,2-trichloroethanol; UDPGA, uridine diphosphate glucuronic acid; UGT, uridine diphosphate glucuronosyl-transferase. 


\section{Materials and Methods}

The materials and sources used in this study are as follows: Dithiothreitol (DTT), EDTA, formic acid, L-glutathione (reduced), imidazole, isopropyl-thio$\beta$-D-galactopyranoside, lysogeny broth (LB), lysozyme, morphine, morphine-3$\beta$-D-glucuronide, morphine-6- $\beta$-D-glucuronide, pepstatin A, polyvinyl sulfonic acid, potassium phosphate, tetrabutylammonium hydrogen sulfate, 2,2,2-trichloroethanol (TCE), and uridine diphosphate glucuronic acid (UDPGA) were the highest grade available from Sigma. Ampicillin, acetonitrile, BSA, HEPES, potassium acetate, $\mathrm{KCl}, \mathrm{KOH}, \mathrm{LiCl}$, magnesium acetate, $\mathrm{MgCl}_{2}, \mathrm{NaCl}, \mathrm{NaAc}$, $\mathrm{NAD}^{+}, \mathrm{NADH}$, phenylmethylsulfonyl fluoride (PMSF), saccharolactone, sodium cholate, TRIS, Tube-O-Dialyzer (MWCO $2000 \mathrm{Da}$ ), uranyl formate, and Whatman filter paper were purchased from Fisher Scientific. Creatine phosphate was purchased from Tokyo Chemical Industry Co., Ltd. Supersomes (microsomes isolated from sf9 insect cells expressing UGT2B7) were purchased from Corning. Hexokinase (yeast) was purchased from Roche Applied Science. Human SULT1E1, SULT2A1, PreScission Protease and GST4A were synthesized as described previously (Zhang et al., 1998; Cook et al., 2019). TnT T7 Insect Cell Extract Protein Expression System was purchased from Promega. Gibson Assembly kit, T7 RNA polymerase, and rNTPs were purchased from New England Biolabs. 4-methylumbelliferone (4-MU), and palmitoyl-2-oleoyl-snglycero-3-phosphocholine (POPC) were purchased from Santa Cruz Biotechnology. Glutathione- and nickel-chelating resins, and Superdex 200 Increase 10/300 GL columns were obtained from GE Life Sciences. The PEPP column (Ultra PEPP $150 \times 4.6 \mathrm{~mm}, 3 \mu \mathrm{m}$ ) was obtained from Restek. Cardiolipins were purchased from Avanti Polar Lipids. Electron microscopy grids were purchased from Electron Microscope Sciences. Competent Escherichia coli [BL21(DE3)] was purchased from Novagen. MidiPrep DNA Extraction Kits were purchased from Qiagen. XL1 Blue competent cells and XL-10 Gold ultracompetent cells were obtained from Agilent. Gibson Assembly Kits and DpnI were purchased from New England Biolabs. The UGT2B7 coding region described in Construction of Expression Vectors was purchased from transOMIC Technologies Inc. MSP1D1 in the p28a vector (Hagn et al., 2013) was purchased from Addgene.

\section{Construction of Expression Vectors}

UGT2B7. The open reading frame of mature UGT2B7 [residues 25-525 (Meech and Mackenzie, 1998; Ouzzine et al., 1999)] was inserted into the Nde I site of pSKB4 (Andreassi and Leyh, 2004), which attaches a PreScission-Protease cleavable, HIS/GST-tag to the N terminus of the UGT coding region. Using Gibson assembly (Gibson et al., 2009), the HIS/GST-fusion protein sequence was inserted into the insect expression vector, pF25A (Ezure et al., 2006). Plasmid was purified [MidiPrep DNA Extraction Kit (Qiagen)] from BL21 E. coli grown in LB medium (Ezure et al., 2006). To prevent toxicity in E. coli, UGT2B7 expression was suppressed with glucose (2.0\%) (Zhang et al., 2003).

MSP1D1. The MSP1D1 coding region in p28a was purchased from Addgene. Using Gibson assembly (Gibson et al., 2009), the coding region was transferred from p28a to pGEX-6P (Cook et al., 2017, 2019), which attaches a PreScissionProtease cleavable, MBP/GST/HIS-tag to the MSP1D1 amino terminus.

RNA Synthesis with T-7 RNA Polymerase. RNA was synthesized by adding $10 \mu \mathrm{g}$ of UGT2B7-pU25 to a $200 \mu \mathrm{l}$ (final volume) reaction mixture containing $2.0 \mathrm{U}$ of T7 RNA polymerase, $4.0 \mathrm{mM}$ of each rNTP, polyvinyl sulfonic acid $(10 \mu \mathrm{g} / \mathrm{ml}), \mathrm{MgCl}_{2}(20 \mathrm{mM})$, and the T7 NEB buffer reaction mix. Reactions were incubated for 4 hours at $37^{\circ} \mathrm{C}$. RNA was precipitated by addition of $20 \mu \mathrm{l}$ of $\mathrm{NaAc}(3.0 \mathrm{M})$ followed by $200 \mu \mathrm{l}$ of isopropanol $\left(4^{\circ} \mathrm{C}\right)$. The sample was incubated overnight at $-20^{\circ} \mathrm{C}$. The RNA was then pelleted at $15,000 \mathrm{~g}$ for

TABLE 1

Nanodisc and microsomal UGT2B7 initial-rate parameters

\begin{tabular}{llccc}
\hline Substrate & $\mathrm{K}_{\mathrm{m}}(\mu \mathrm{M})$ & $\begin{array}{c}\mathrm{k}_{\mathrm{cat}} \\
\left(\mathrm{s}^{-1}\right)\end{array}$ & $\mathrm{K}_{\mathrm{i}}(\mu \mathrm{M})$ & $\begin{array}{c}\mathrm{k}_{\mathrm{cat} \text { inh }} \\
\left(\mathrm{s}^{-1}\right)\end{array}$ \\
\hline $\begin{array}{l}\text { Nanodisc } \\
\text { UDPGA }\end{array}$ & $260(17)^{a}$ & $2.2(0.2)$ & - & - \\
4-MU & $170(15)$ & $2.2(0.3)$ & $1100(30)$ & $0.96(0.05)$ \\
Microsome & & & & \\
UDPGA & $300(23)^{a}$ & $1.8(0.2)$ & & \\
4-MU & $200(12)$ & $1.9(0.2)$ & & \\
\hline
\end{tabular}

${ }^{a}$ Parentheses enclose one S.D. unit.
1.0 hour. The supernatant was decanted, and the pellet was washed with $200 \mu \mathrm{l}$ of $70 \%$ ethanol (ambient temperature) and spun at 15,000 g for $15 \mathrm{~min}$. Ethanol was removed and the pellet was air-dried for $5 \mathrm{~min}$ on ice before resuspension in $30 \mu \mathrm{l}$ of RNAse free water. RNA degradation was assessed using agarose gels. RNA was quantitated at $260 \mathrm{~nm}$, and the 260/280 ratio was used to estimate its purity.

MSP1D1 Expression and Purification. E. coli [BL21(DE3)] containing MSP1D1 expression vector were grown at $37^{\circ} \mathrm{C}$ in LB medium (Cook et al., 2017). At $\mathrm{OD}_{600} \sim 0.6$, the culture was cooled in an ice/water bath. Upon reaching $17^{\circ} \mathrm{C}$, isopropyl-thio- $\beta$-D-galactopyranoside was added $(0.30 \mathrm{mM}$ final $)$ and the culture was incubated at $17^{\circ} \mathrm{C}$ for 16 hours. Cells were then pelleted and resuspended in lysis buffer [PMSF $(290 \mu \mathrm{M})$, pepstatin A $(1.5 \mu \mathrm{M})$, lysozyme $(0.10 \mathrm{mg} / \mathrm{ml})$, EDTA $(2.0 \mathrm{mM}), \mathrm{KCl}(400 \mathrm{mM}), \mathrm{K}_{2} \mathrm{PO}_{4}(50 \mathrm{mM}), \mathrm{pH}$ 7.5]. The suspension was sonicated and then centrifuged $\left(10,000 \mathrm{~g}, 1.0\right.$ hour, $\left.4^{\circ} \mathrm{C}\right) . \mathrm{MgCl}_{2}$ $(5.0 \mathrm{mM})$ was added to chelate EDTA before passing the solution through a Chelating Sepharose Fast Flow column charged with $\mathrm{Ni}^{2+}$. The column was washed [imidazole $(10 \mathrm{mM}), \mathrm{KCl}(400 \mathrm{mM})$, and $\mathrm{KPO}_{4}(50 \mathrm{mM}), \mathrm{pH} 7.5$ ], enzyme was eluted [imidazole $(250 \mathrm{mM}), \mathrm{KCl}(400 \mathrm{mM})$, and $\mathrm{KPO}_{4}(50 \mathrm{mM}), \mathrm{pH}$ 7.5] and loaded directly onto a Glutathione Sepharose column. The GST column was washed [DTT $(2.0 \mathrm{mM}), \mathrm{KCl}(400 \mathrm{mM})$, and $\mathrm{KPO}_{4}(50 \mathrm{mM}), \mathrm{pH} 7.5$ ] before eluting the tagged enzyme [reduced glutathione $(10 \mathrm{mM}), \mathrm{DTT}(2.0 \mathrm{mM}), \mathrm{KCl}$ $(400 \mathrm{mM})$, and Tris $(100 \mathrm{mM}), \mathrm{pH} 8.0]$. The fusion protein was digested overnight at $4^{\circ} \mathrm{C}$ using PreScission Protease and passed through a GST column to remove the tag and excess protease. A dipeptide (GlyGln-) remains at the $\mathrm{N}$ terminus of the protein following cleavage. The protein was $\geq 95 \%$ pure as judged by SDSPAGE, and its concentration was determined by UV absorbance $\left[\mathcal{E}_{280}=\right.$ $18.2 \mathrm{mM}^{-1} \mathrm{~cm}^{-1}$ (Civjan et al., 2003; Denisov et al., 2004)]. The protein was then concentrated, flash frozen, and stored at $-80^{\circ} \mathrm{C}$

Expression and Purification of UGT2B7•Nanodiscs. UGT2B7 was expressed using the TnT T7 Insect Cell Extract Protein Expression System (Promega). The extract was supplemented with POPC $(6.0 \mathrm{mM})$, sodium cholate (12 $\mathrm{mM})$, and purified MSP1D1 (100 $\mu \mathrm{M})$. Expression was initiated by addition of UGT2B7 mRNA $(\sim 500 \mu \mathrm{g})$ to a final volume of $1.0 \mathrm{ml}$ in a Tube-O-Dialyzer, MWCO $2000 \mathrm{kDa}$. The reaction was dialyzed against $20 \mathrm{ml}$ of HEPES $(40 \mathrm{mM})$, potassium acetate $(100 \mathrm{mM})$, magnesium acetate $(2.0 \mathrm{mM})$, cardiolipids $(6.0$ $\mathrm{mM})$, sodium cholate $(12 \mathrm{mM})$, ATP $(0.50 \mathrm{mM})$, GTP $(0.25 \mathrm{mM})$, creatine phosphate $(20 \mathrm{mM}), 20$ amino acids $(100 \mu \mathrm{M}$ each $)$, DTT (2.0 mM), EDTA $(0.25$ $\mathrm{mM}$ ), and PMSF $(0.50 \mathrm{mM}), \mathrm{pH}$ 7.9. The reaction was run at $15^{\circ} \mathrm{C}$. Dialysis buffer was replaced every $48 \mathrm{~h}$. Expression was monitored using SDS-PAGE and the reaction reached completion after 4 days.

Unless specified otherwise, buffers were equilibrated and manipulations were performed at $4{ }^{\circ} \mathrm{C}$. Following UGT expression, the extract was dialyzed three times over $24 \mathrm{~h}$ against 1.01 of HEPES $(40 \mathrm{mM}), \mathrm{KCl}(100 \mathrm{mM}), \mathrm{pH}$ 7.9. Extract was then centrifuged $(15,000 \mathrm{~g}, 10.0$ minute $)$ and the supernatant was incubated in a spin cup for $8 \mathrm{~h}$ with $100 \mu \mathrm{l}$ of Chelating Sepharose Fast Flow resin charged with $\mathrm{Ni}^{2+}$ and equilibrated in dialysis buffer (Radchenko et al., 2010). The cup was then spun $(100 \mathrm{~g}, 1.0$ minute) and the resin was suspended and spun three times in $300 \mu \mathrm{l}$ of His wash buffer [HEPES $(40 \mathrm{mM})$, imidazole $(25 \mathrm{mM}), \mathrm{KCl}$ $(100 \mathrm{mM}), \mathrm{pH} 7.9]$. UGT2B7 nanodiscs were then eluted with His elution buffer [imidazole $(250 \mathrm{mM}), \mathrm{KCl}(400 \mathrm{mM})$, and $\mathrm{KPO}_{4}(50 \mathrm{mM}), \mathrm{pH}$ 7.5]. Nanodiscs were then incubated for $4 \mathrm{~h}$ with $50 \mu \mathrm{l}$ of Glutathione Sepharose resin equilibrated with GSH wash buffer [DTT (2.0 mM), $\mathrm{KCl}(400 \mathrm{mM})$, and $\mathrm{KPO}_{4}(50 \mathrm{mM}), \mathrm{pH}$ 7.5]. The resin was then spun $(100 \mathrm{~g}, 1.0$ minute) and washed and spun three times with $100 \mu \mathrm{l}$ of GSH wash buffer. Nanodiscs were eluted using $100 \mu \mathrm{l} \mathrm{GSH}$ elution buffer [reduced glutathione $(10 \mathrm{mM})$, DTT $(2.0 \mathrm{mM}), \mathrm{KCl}(400 \mathrm{mM})$, and $\left.\mathrm{KPO}_{4}(50 \mathrm{mM}), \mathrm{pH} 7.5\right]$. The purified fusion protein was then digested during overnight dialysis using PreScission Protease $(0.4 \mu \mathrm{M})$. A GlnGly-dipeptide remains at the $\mathrm{N}$ terminus of the coding region following cleavage. Dialysis was repeated three times against 1.01 of phosphate buffer $\left[\mathrm{KPO}_{4} 40 \mathrm{mM}, \mathrm{KCl}(100\right.$ $\mathrm{mM}), \mathrm{pH}$ 7.5]. PreScission Protease and the fusion tag were removed by passing the proteolyzate over $\sim 100 \mu \mathrm{l}$ of GST resin equilibrated with phosphate buffer. Finally, to remove aggregates and nanodisc stacks, the solution was passed through a size exclusion column (Superdex 200 Increase 10/300) equilibrated at ambient temperature in phosphate buffer. UGT2B7 was quantitated by comparing its fluorescence to that of purified standards (MSP1D1, SULT2A1, SULT1E1, Hexokinase, and GST4A) in TCE-treated SDS-PAGE gels (Chopra et al., 2019). The purity of the final UGT2B7 preparation was estimated, using SDS PAGE, at $\sim 95 \%$. The protocol yielded $1.2 \mathrm{mg}$ of UGT2B7 per $\mathrm{ml}$ of cell-free extract. The purified UGT2B7 nanodiscs were flash frozen in liquid nitrogen and stored in 

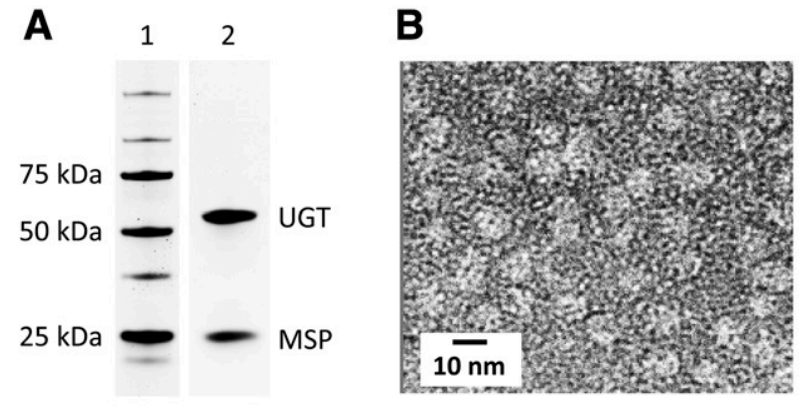

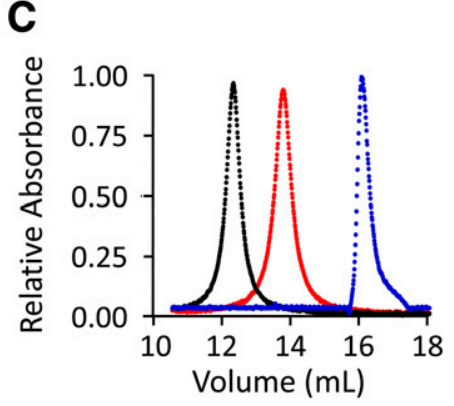

Fig. 1. Purity and homogeneity of the UGT2B7•nanodisc. (A) SDS-PAGE analysis. Lane 1, molecular weight standards; lane 2, purified UGT2B $7 \bullet$ nanodiscs $(1.0 \mu \mathrm{g})$. Proteins were visualized via protein fluorescence in TCE-infused gels (see Results and Discussion). (B) Negative stain, EM image of the purified UGT2B7•nanodisc (original magnification, $50,000 \times)$. (C) Size-exclusion chromatography. Each color-coded peak represents the chromatographic profile of a purified component: UGT2B7•nanodisc $(0.14 \mathrm{mg}$, black), empty nanodisc $(0.11 \mathrm{mg}$, red), and free MSP1D1 $(0.11 \mathrm{mg}$, blue). Protein was monitored at 280 $\mathrm{nm}$, and the peaks were normalized to the highest measured absorbance. aliquots at $-80^{\circ} \mathrm{C}$. The samples showed no loss of activity over 6 months at $-80^{\circ} \mathrm{C}$, they are stable for more than 3 days at $4^{\circ} \mathrm{C}$, and their activity begins to deteriorate after three freeze/thaw cycles.

Negative Staining. Four microliters of purified UGT॰nanodiscs $(0.55 \mathrm{mg} / \mathrm{ml})$ was layered onto carbon-coated 400-mesh electron-microscope grids. Excess liquid was removed from the grids by blotting from the side with Whatman paper \#1. The grids were then washed two times with distilled water, stained twice with $1 \%$ uranyl formate solution, and UV-irradiated for 5.0 minute before imaging using a TVIPS F416 camera at 50,000× magnification (Tan et al., 2006).

4-MU Binding to BSA. The binding of 4-MU was monitored via ligandinduced decrease in the intrinsic fluorescence of BSA $\left(\lambda_{\mathrm{ex}}=285 \mathrm{~nm}, \lambda_{\mathrm{em}}=\right.$ $330 \mathrm{~nm})$. BSA fluorescence decreased $33 \%$ at saturation. 4-MU $(10 \mu \mathrm{M}$ to $10 \mathrm{mM}$ ) was titrated into a solution containing BSA (1.0\%), $\mathrm{MgCl}_{2}(5.0 \mathrm{mM})$, $\mathrm{KPO}_{4}(50 \mathrm{mM}), \mathrm{pH} 7.5,25 \pm 2^{\circ} \mathrm{C}$. Titrations were performed in duplicate. Data were averaged and least-squares fit using the quadratic equation to a model that assumes a single binding site per subunit. $\mathrm{K}_{\mathrm{d}}$ for 4-MU, BSA interaction was $380 \pm 21 \mu \mathrm{M}$.

Initial-Rate Studies. Reaction progress was monitored via the fluorescence decrease associated with 4-MU glucuronidation $\left(\lambda_{\mathrm{ex}}=370 \mathrm{~nm}, \lambda_{\mathrm{em}}=451 \mathrm{~nm}\right)$ (Uchaipichat et al., 2004). Rate measurements were performed at a fixedsaturating concentration of one substrate and varied the other from $0.20 \mathrm{~K}_{\mathrm{m}}$ to $5.0 \mathrm{~K}_{\mathrm{m}}$ in equal increments in double-reciprocal space. For experiments involving $\mathrm{BSA}$, the total 4-MU concentration required to achieve the intended free 4-MU concentration was calculated using the $\mathrm{K}_{\mathrm{d}}$ for $4-\mathrm{MU}$ binding to BSA. At [4-MU] free ranging from 0.20 to $5.0 \times \mathrm{K}_{\mathrm{m}}$, BSA-bound 4-MU ranged from $5 \%$ to $17 \%$ of the total 4-MU added. Supersome studies involved incubating fresh Supersomes $(5.0 \mathrm{mg} / \mathrm{ml})$ with alamethicin $(25 \mu \mathrm{M})$ and saccharolactone $(5.0 \mathrm{mM})$ for $60 \mathrm{~min}$ in an ice-water bath $\left(\sim 0^{\circ} \mathrm{C}\right)$ prior to reaction. Reaction conditions were as follows: UGT2B7 (100 nM, active site) or UGT2B7 supersomes (50 $\mu \mathrm{g})$, BSA ( 0 or $1.0 \% \mathrm{wt} / \mathrm{vol})$, alamethicin $(25 \mathrm{nM}$, Supersomes only), saccharolactone

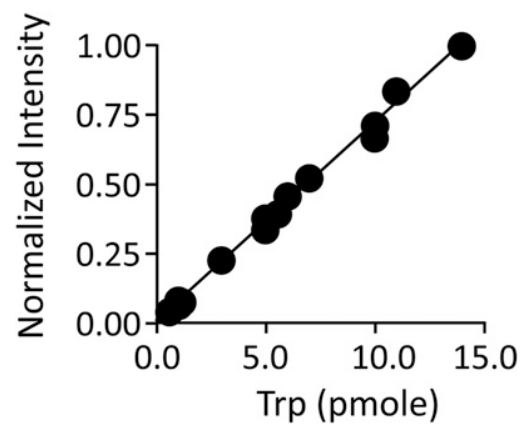

Fig. 2. Standard curve to determine UGT2B7:nanodisc stoichiometry. The normalized fluorescent intensity of protein-standard bands in TCE-infused SDSPAGE gels is plotted vs. picomole of Trp calculated from known amino acid compositions and extinction coefficients. Intensities are normalized relative to the maximum measured intensity. The standard curve was constructed using five purified proteins [MSP1D1 (synthetic), SULT2A1 (human), SULT1E1 (human), hexokinase (yeast), and GST4A (human)], each of which was loaded at three different concentrations. Fluorescence intensity $\left(\lambda_{\mathrm{ex}}=310 \mathrm{~nm}, \lambda_{\mathrm{em}} \geq 500 \mathrm{~nm}\right)$ was quantitated using Image Laboratory Software.
(5.0 $\mu \mathrm{M}$, Supersomes only), $\mathrm{MgCl}_{2}(5.0 \mathrm{mM}), \mathrm{KPO}_{4}(50 \mathrm{mM}), \mathrm{pH} 7.5,25 \pm 2^{\circ} \mathrm{C}$. The fixed-saturating concentrations of UDPGA and 4-MU were $5.0 \mathrm{mM}$ $\left(21 \times \mathrm{K}_{\mathrm{m}}\right)$ and $3.5 \mathrm{mM}\left(20 \times \mathrm{K}_{\mathrm{m}}\right)$, respectively. Reactions were initiated by adding UDPGA to a final volume of $500 \mu \mathrm{l}$, and reaction progress was monitored via the fluorescence decrease associated with 4-MU glucuronidation $\left(\lambda_{\mathrm{ex}}=\right.$ $370 \mathrm{~nm}, \lambda_{\mathrm{em}}=451 \mathrm{~nm}$ ). In all cases, less than $5 \%$ of the concentration-limiting substrate consumed at the reaction end point was converted to product during the measurement. Initial-rate constants were estimated using a weighted-least-squares fit to a simple Michaelis-Menten model using sequeno (Cleland, 1979).

Partial Substrate Inhibition. 4-MU partial-substrate inhibition was evaluated under the following conditions: UGT2B7 (100 nM, active site), 4-MU (0.16-11 mM, 0.15-10 $\left.\times \mathrm{K}_{\mathrm{i}}\right)$, UDPGA $\left(5.0 \mathrm{mM}, 21 \times \mathrm{K}_{\mathrm{m}}\right), \mathrm{MgCl}_{2}(5.0 \mathrm{mM})$, $\mathrm{KPO}_{4}(50 \mathrm{mM}), \mathrm{pH} 7.5,25 \pm 2^{\circ} \mathrm{C}$. Reaction progress was monitored via the decrease of fluorescence associated with 4-MU glucuronidation $\left(\lambda_{\mathrm{ex}}=370 \mathrm{~nm}\right.$, $\left.\lambda_{\mathrm{em}}=451 \mathrm{~nm}\right)$. Initial-rate kinetic parameters were obtained by least-squares fitting to an uncompetitive, partial-inhibition model (Yoshino and Murakami, 2015; Wang et al., 2016) using solver (Excel 2007, Microsoft). Fitting was initiated using initial-rate parameters obtained from Initial-Rate Studies $\left(\mathrm{k}_{\mathrm{cat}}, \mathrm{K}_{\mathrm{m}}\right)$ and graphical analysis of the data $\left(\mathrm{k}_{\mathrm{cat}}\right.$ inh, $\left.\mathrm{K}_{\mathrm{i}}\right)$. The parameters are reported in Table 1 .

Albumin-Effect Assays. UGT2B7 Supersomes were incubated prior to reaction with alamethicin and saccharolactone as described above (see InitialRate Studies). Reaction conditions were as follows: UGT2B7 [nanodisc $(50 \mathrm{nM})$, or microsomes $(25 \mu \mathrm{g})]$, BSA ( 0 or $1.0 \%)$, 4-MU $\left(20 \mu \mathrm{M}, 0.12 \times \mathrm{K}_{\mathrm{m}}\right)$, UDPGA $\left(5.0 \mathrm{mM}, 21 \times \mathrm{K}_{\mathrm{m}}\right)$, alamethicin $(12.5 \mathrm{nM}$, Supersomes only), saccharolactone (2.5 $\mu \mathrm{M}$, Supersomes only), $\mathrm{MgCl}_{2}(5.0 \mathrm{mM}), \mathrm{KPO}_{4}$ buffer $(50 \mathrm{mM}), \mathrm{pH} 7.5$, $25^{\circ} \mathrm{C}$. Reactions were initiated by addition of UDPGA to a final volume of $500 \mu \mathrm{l}$. Reaction progress was monitored via the fluorescence decrease associated with 4-MU glucuronidation $\left(\lambda_{\mathrm{ex}}=370 \mathrm{~nm}, \lambda_{\mathrm{em}}=451 \mathrm{~nm}\right)$.

Rate Studies Using Morphine. Reaction conditions were as follows: UGT2B7 nanodisc (100 nM, UGT active site) or UGT2B7 Supersomes $\left(100 \mu \mathrm{g} \mathrm{ml}^{-1}\right)$, morphine $(100 \mu \mathrm{M})$, UDPGA $\left(5.0 \mathrm{mM}, 21 \times \mathrm{K}_{\mathrm{m}}\right)$, BSA ( $1.0 \% \mathrm{wt} / \mathrm{vol}$, Supersomes only), alamethicin (25 nM, Supersomes only), saccharolactone $\left(5.0 \mu \mathrm{M}\right.$, Supersomes only), $\mathrm{MgCl}_{2}$ (5.0 mM), $\mathrm{KPO}_{4}$ $(50 \mathrm{mM}), \mathrm{pH} 7.5,25 \pm 2^{\circ} \mathrm{C}$. Reactions were initiated by addition of UDGPA. To ensure initial rates were measured, less than $5 \%$ of the morphine consumed at the end point of the reaction was formed during the measurement. Reactions were quenched by addition of $1.0 \mathrm{~N} \mathrm{NaOH}$ (final concentration, $0.10 \mathrm{~N}$ ) and neutralized $5 \mathrm{~min}$ later by addition of $1.0 \mathrm{~N} \mathrm{HCL}$. Eppendorf tubes containing $100 \mu \mathrm{l}$ reaction aliquots were placed in a boiling water bath $(5 \mathrm{~min})$ and then spun at $15,000 \mathrm{~g}$ $(5 \mathrm{~min})$. The supernatant was diluted $(1 / 20 \mathrm{v} / \mathrm{v})$ in water/formic acid $(0.10 \% \mathrm{v} / \mathrm{v})$, loaded onto an Ultra PEPP HPLC column, and reactants were separated using an acetonitrile gradient (Suominen et al., 2013). Supersomes $(5.0 \mathrm{mg} / \mathrm{ml})$ were incubated with alamethicin $(25 \mu \mathrm{M})$ and saccharolactone $(5.0 \mathrm{mM})$ for $60 \mathrm{~min}$ in an ice-water bath $\left(\sim 0^{\circ} \mathrm{C}\right)$ prior to reaction.

\section{Results and Discussion}

Assembly and Purification of UGT2B7•MSP1D1 Nanodiscs. An expression plasmid that attaches a PreScission-Protease removable, HIS/ GST-dual tag to the N terminus of the mature form of UGT2B7 [which lacks 25 N-terminal amino acids (Meech and Mackenzie, 1998)] was 

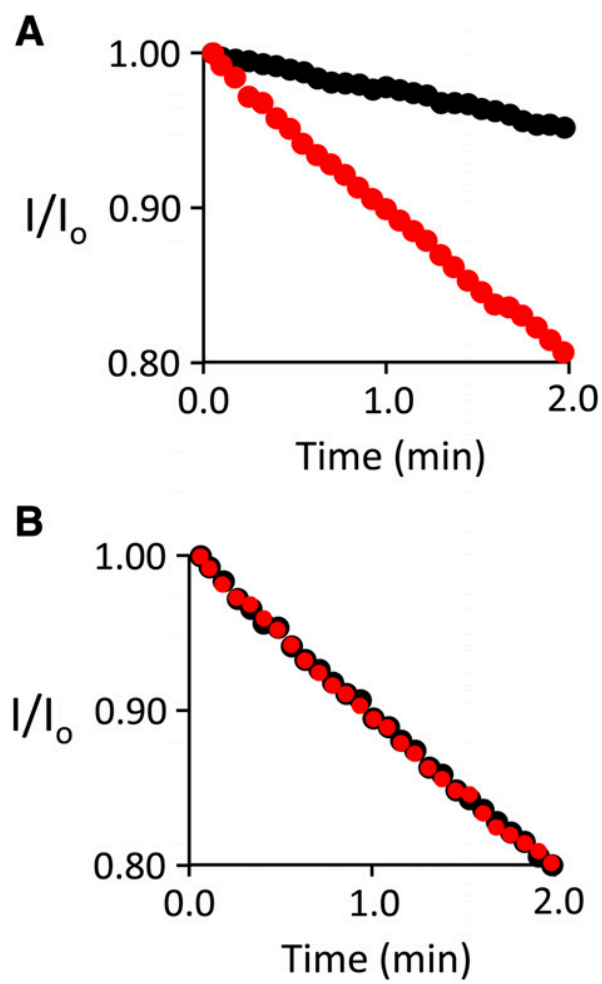

Fig. 3. Albumin effects on nanodisc and microsomal UGT2B7 turnover. (A) Microsomal UGT2B7. Supersomes $(5.0 \mathrm{mg} / \mathrm{ml})$ were incubated with alamethicin $(25 \mu \mathrm{M})$ and saccharolactone $(5.0 \mathrm{mM})$ for $60 \mathrm{~min}$ in an ice-water bath $\left(\sim 0^{\circ} \mathrm{C}\right)$ prior to reaction. Reaction conditions: Supersomes ( $25 \mu \mathrm{g}$ protein), BSA ( 0 , black dots, or $1.0 \% \mathrm{wt} / \mathrm{vol}$, red dots), 4-MU $\left(20 \mu \mathrm{M}, 0.12 \times \mathrm{K}_{\mathrm{m}}\right)$, alamethicin $(12.5 \mathrm{nM})$, saccharolactone $(2.5 \mu \mathrm{M})$, UDPGA $\left(5.0 \mathrm{mM}, 20 \times \mathrm{K}_{\mathrm{m}}\right), \mathrm{MgCl}_{2}(5.0 \mathrm{mM}), \mathrm{KPO}_{4}$ buffer $(50 \mathrm{mM}), \mathrm{pH} 7.5,25^{\circ} \mathrm{C}$. Reactions were initiated by adding UDPGA to a final volume of $500 \mu \mathrm{l}$, and reaction progress was monitored via the fluorescence decrease associated with 4-MU glucuronidation $\left(\lambda_{\mathrm{ex}}=370 \mathrm{~nm}, \lambda_{\mathrm{em}}=451 \mathrm{~nm}\right)$. (B) The UGT2B7•nanodisc. Assays were identical to (A) except that Supersomes were replaced with the UGT2B7•nanodisc $(50 \mathrm{nM})$, and alamethicin and saccharolactone were absent.

constructed (see Materials and Methods) and used to test expression of the fusion protein in extracts from E. coli, Saccharomyces cerevisiae, wheat germ, and sf9 insect cells. Consistent with the UGT codon bias, expression is significantly (15-20-fold) greater in the insect cell extract. Expression was enhanced by continuous dialysis of the extract against buffer containing protein synthesis reagents (see Materials and Methods). Assembly of nanodiscs was accomplished by adding pure MSP (MSP1D1), phospholipids (POPC and cardiolipin), and bile acid (sodium cholate) to the insect extract. Nanodiscs form spontaneously and incorporate UGT2B7 as cholate is removed by dialysis (Civjan et al., 2003).

UGT2B7•nanodiscs were purified successively over His- and GSTaffinity resins. Empty nanodiscs lack affinity tags and are thus not expected to bind these resins significantly. However, the empty discs can form aggregates, or "stacks," with UGT2B7•nanodiscs (B Kumar et al., 2017). Stacks comprised $\sim 10 \%$ of the affinity purified UGT2B7•nanodiscs and were removed using size exclusion chromatography. SDSPAGE analysis of the size exclusion chromatography-purified UGT2B7•nanodiscs (Fig. 1A) reveals that the preparation contains highly purified UGT2B7 and MSP1D1. Negative-staining electron microscopy of the nanodisc preparations (Fig. 1B) shows fields of discoidal structures whose dimensions $(\sim 10 \mathrm{~nm})$ are consistent with those expected for MSP1D1 nanodiscs (Civjan et al., 2003; B Kumar et al., 2017). The homogeneity of the UGT2B7•nanodisc preparation was further assessed using size-exclusion chromatography. Chromatograms of purified UGT2B7•nanodiscs (black), empty nanodiscs (red), and MSP1D1 protein (blue) are superposed in Fig. 1C. The UGT2B7•nanodisc peak is highly symmetric, suggesting a homogeneous preparation, and is well isolated from contaminants that would be transparent to the SDS-PAGE and negative staining methods.

UGT2B7 Oligomerization. The oligomerization status of UGTs remains an open question. Although most studies support that microsomal UGTs are dimeric (Meech and Mackenzie, 1997; Yuan et al., 2015), others suggest monomers (Peters et al., 1984; Vessey and Kempner, 1989). Given that nanodiscs harbor two MSPs (Civjan et al., 2003; B Kumar et al., 2017), the number of 2B7 molecules per nanodisc can be calculated from the 2B7:MSP ratio in pure, homogeneous complexes. The 2B7-to-MSP stoichiometry was obtained from the relative fluorescent intensities of the $2 \mathrm{~B} 7$ and MSP protein bands in UVexposed, SDS-PAGE gels infused with TCE. TCE undergoes UV-induced reactions with Trp and Tyr residues (Casas-Finet et al., 1992; Ladner et al., 2006) that allow them to be distinguished based on their fluorescence emission spectra (Chopra et al., 2019). The TCE reactions are covalent, highly efficient (Casas-Finet et al., 1992), and have been used to quantitate proteins in SDS-PAGE gels based on their Trp composition and fluorescent intensity relative to standards (Casas-Finet et al., 1992; Chopra et al., 2019).

To assess the linearity and precision of the TCE method, a standard curve was constructed (Fig. 2) using five highly purified proteins with gravimetrically determined extinction coefficients [human SULT2A1 (Wang et al., 2014), human SULT1E1 (Zhang et al., 1998), yeast hexokinase (Jacob et al., 1991), human GST4A (Mannervik, 1985), and synthetic MSP1D1 (Denisov et al., 2004)]. Notably, MSP1D1 (Denisov et al., 2004) purified from E. coli (see Materials and Methods) was one of the standards. The fluorescent intensities of the standards spanned the range of intensities used to determine the MSP:2B7 stoichiometry. The data demonstrate that the method is highly linear and precise $\left(R^{2}=\right.$ $0.994)$ over the proteins and range of intensities used in the study. The 2B7-to-MSP stoichiometry in the purified nanodisc, determined in triplicate, is $1.02( \pm 0.04)$. This finding strongly suggests that UGT2B7 is a monomer in the nanodisc; however, the analysis does not withstand the possibility that the fluorescent intensity of UGT2B7 per Trp is aberrant such that it yields a well-defined stoichiometry.

UGT2B7 Assays: Nanodiscs versus Microsomes. Given the challenges traditionally associated with UGT purification, in vitro UGT studies are typically carried out using microsomes prepared from cell-lines that overexpress the isoform of interest. Such preparations are complex and pose certain experimental challenges (Zhou and Miners, 2014). For example, microsomes must be perforated, using membrane channel-forming peptides (Fox and Richards, 1982; Bánhegyi et al., 1993), to allow substrates to diffuse into the microsomal lumen and access UGT-active sites. Further, glucuronidase-catalyzed cleavage of the glycosidic bond formed in UGT reactions is often inhibited by addition of saccharolactone (D-glucaro-1,4-lactone), which can also inhibit turnover by direct interaction with UGTs (Robinson et al., 1991; Zhou and Miners, 2014; Argikar, 2018). Finally, endogenous long-chain fatty acids, which can isoform-specifically inhibit UGTs, are frequently "removed" in situ by adsorption using BSA (Rowland et al., 2007, 2008; Manevski et al., 2011). The use of BSA requires that BSA-binding of the UGT substrate be taken into consideration (Manevski et al., 2011). The multiple possible points-of-action of BSA and saccharolactone with components of the microsome assay suggest that the effects of the components should be characterized for each UGT isoform and substrate.

Given the well-known, complex effects of BSA on UGT catalysis in microsomes (Zhou and Miners, 2014), it was of interest to assess its effects on the activity of UGT2B7 $\bullet$ nanodiscs and compare them to those on microsomal UGT2B7. The assays used 4-methylumbelliferone 

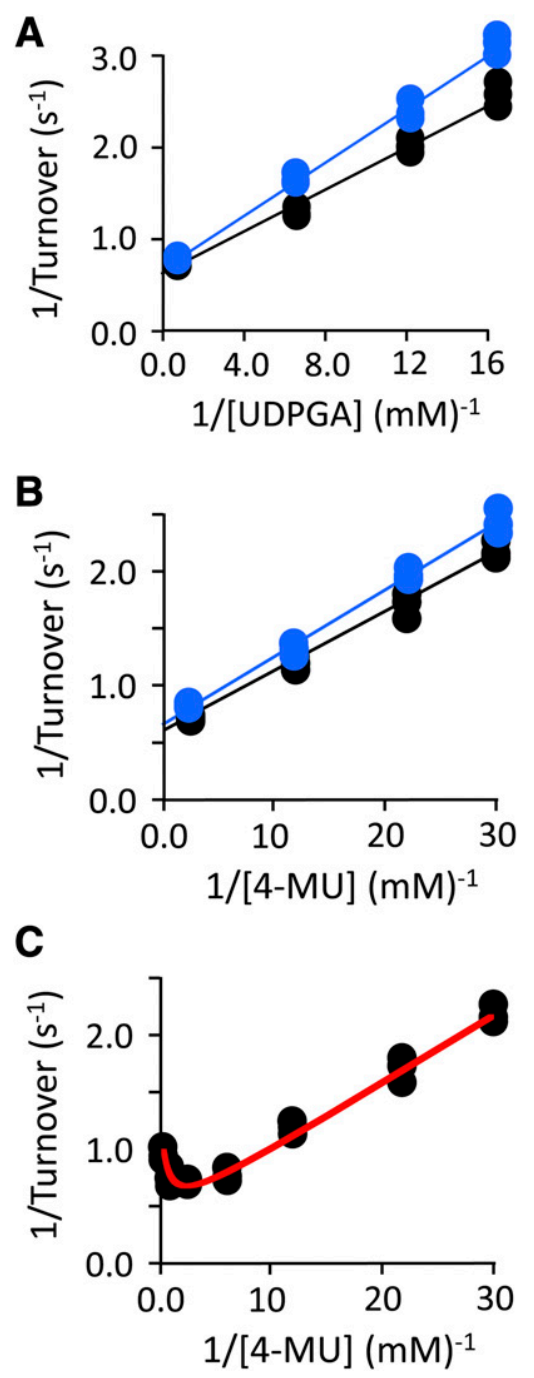

Fig. 4. Initial-rate behavior of UGT2B7 in nanodiscs and microsomes. (A) $1 /$ Turnover vs. 1/[UDPGA]. Reaction conditions: UGT2B7-nanodisc (100 nM active sites, black dots) or UGT2B7 Supersomes (110 $\mu \mathrm{g}$, blue dots), UDPGA $\left(60-1250 \mu \mathrm{M}, 0.2-5 \times \mathrm{K}_{\mathrm{m}}\right), 4-\mathrm{MU}\left(3.5 \mathrm{mM}\right.$ free, $\left.20 \times \mathrm{K}_{\mathrm{m}}\right)$, BSA $(1.0 \% \mathrm{wt} / \mathrm{vol}$, Supersome assay only), $\mathrm{MgCl}_{2}(5.0 \mathrm{mM}), \mathrm{KPO}_{4}(50 \mathrm{mM}), \mathrm{pH} 7.5,25 \pm 2{ }^{\circ} \mathrm{C}$. Supersomes were incubated $\left(0^{\circ} \mathrm{C}, 60 \mathrm{~min}\right)$ with alamethicin $(25 \mu \mathrm{M})$ and saccharolactone $(5.0 \mathrm{mM})$ prior to assay. Reactions were initiated by addition of UDPGA to a final volume of $500 \mu \mathrm{l}$. Reaction progress was monitored via the fluorescence decrease associated with 4-MU glucuronidation $\left(\lambda_{\mathrm{ex}}=370 \mathrm{~nm}, \lambda_{\mathrm{em}}=\right.$ $451 \mathrm{~nm}$ ). (B) $1 /$ Turnover vs. 1/[4-MU]. Assays were identical to (A) except [UDPGA] was fixed $\left(5.0 \mathrm{mM}, 21 \times \mathrm{K}_{\mathrm{m}}\right)$ and [4-MU] was varied from 35 to $900 \mu \mathrm{M}\left(0.2-5 \times \mathrm{K}_{\mathrm{m}}\right)$. (C) 4-MU substrate inhibition. Assays were identical to (B) except [4-MU] was varied from 0.035 to $11 \mathrm{mM}\left(0.03-10 \times \mathrm{K}_{\mathrm{i}}\right)$. Initial-rate parameters were obtained by weighted-least-squares fitting to either a simple Michaelis-Menten (A and B) or a partial substrate inhibition model (C). Initial-rate parameters are compiled in Table 1.

(4-MU) as the substrate acceptor, and reaction progress was monitored via the fluorescence decrease associated with 4-MU glucuronidation $\left(\lambda_{\mathrm{ex}}=370 \mathrm{~nm}, \lambda_{\mathrm{em}}=451 \mathrm{~nm}\right)$ (Uchaipichat et al., 2004). UDPGA was saturating $\left(5.0 \mathrm{mM}, 21 \times \mathrm{K}_{\mathrm{m}}\right)$; 4-MU was subsaturating $\left(0.12 \times \mathrm{K}_{\mathrm{m}}\right)$ to allow $\mathrm{k}_{\text {cat }}$ and/or $\mathrm{K}_{\mathrm{m}}$ 4-MU effects to be detected. Preincubation with alamethicin, a pore-forming peptide, and saccharolactone was needed to optimize turnover of the microsomal preparation but had no effect on UGT2•B7nanodisc activity. BSA was set either at zero or $1.0 \%(\mathrm{wt} / \mathrm{vol})$. Reactions were run at $25^{\circ} \mathrm{C}$ and were initiated by addition of UDPGA. Further details are given in Materials and Methods, subsection AlbuminEffect Assays. As is evident (Fig. 3A), the velocity of the 4-MU reaction is substantially (4.6-fold) faster in the presence (red dots) of BSA than in its absence (black dots). In contrast, BSA has no detectible effect on turnover of the UGT2B7•nanodisc (Fig. 3B). Thus, several of the experimental challenges associated with assaying UGTs in microsomes are circumvented by the $2 \mathrm{~B} 7 \bullet$ nanodisc system.

Initial-Rate Studies. The initial-rate parameters of nanodisc- and microsomal-UGT2B7 toward UDPGA and 4-MU were determined. The experimental design holds the concentration of one substrate fixed and saturating while varying the other from 0.2 to $5 \times \mathrm{K}_{\mathrm{m}}$ in equal increments in double reciprocal space; consequently, the constants are apparent rather than true kinetic constants. The microsome experiments used fresh Supersomes (i.e., commercial microsomes isolated from sf9 cells that overexpress recombinant UGTs). To correct the 4-MU concentration in the microsome studies for 4-MU binding to BSA, $\mathrm{K}_{\mathrm{d}}$ for the interaction, $380 \pm 21 \mu \mathrm{M}$, was determined via 4-MU induced changes in BSA intrinsic fluorescence (see Materials and Methods, subsection BSA Binding to 4-MU). The UGT2B7 concentration in Supersomes $(925 \pm 126 \mathrm{pmol} / \mathrm{mg}$ extract) (Fallon et al., 2013) was used to calculate 2B7 turnover in the microsomal studies.

The initial-rate-study 1/v-versus-1/[S] plots can be seen in Fig. 4. Black and blue dots (Fig. 4, A and B) reference the nanodisc and microsomal studies, respectively. Lines passing through the data represent the behavior predicted by initial-rate parameters obtained by weighted least-squares fitting (see Materials and Methods, subsection Initial-Rate Studies). The best-fit parameters are provided in Table 1. The data in Fig. 4, A and B reveal that the initialrate parameters of UGT2B7 in the nanodisc and microsome are quite similar - they differ by less than one S.D. Extending the 4-MU concentration beyond $5 \times \mathrm{K}_{\mathrm{m}}$ (Fig. 4C) reveals substrate inhibition, which has been reported for 4-MU with other UGT isoforms (Uchaipichat et al., 2004), Fig. 4C. The red line passing through the Fig. 4C data are the best-fit prediction obtained using an uncompetitive, partial-inhibition model (see Materials and Methods, subsection Partial Substrate Inhibition).

The catalytic integrity of the nanodisc complex was further examined using morphine, which exhibits high specificity for the $2 \mathrm{~B} 7$ isoform (Court et al., 2003; Stone et al., 2003). Morphine is glucuronidated at the $3-\mathrm{OH}$ by numerous isoforms, while glucuronidation at the $6-\mathrm{OH}$ is highly specific for $2 \mathrm{~B} 7$. The catalytic efficiency (i.e., V/K) of $2 \mathrm{~B} 7$ toward the three- and six-positions varies such that at subsaturating morphine (i.e., where reaction rates are linear with $\mathrm{V} / \mathrm{K}$ ) initial-rate measurements yield a product ratio of approximately 6-to-1 in favor of the three-position (Stone et al., 2003). The relative rates of reaction at the three- and six-positions provide a simultaneous measure of the partitioning between these two catalytic paths. At saturating UDPGA, the apparent $\mathrm{K}_{\mathrm{m}}$ of morphine for the three- and six-conjugation reactions is reported to range from 0.5 to $1.0 \mathrm{mM}$ (Court et al., 2003; Stone et al., 2003). To compare the partitioning of these reactions in the nanodisc and microsomes preparations, the rates of formation and distribution of the three- and six-conjugates were determined under subsaturating, initialrate conditions (see Materials and Methods). Morphine reactants were separated using reverse-phase HPLC and quantitated using absorbance at $285 \mathrm{~nm}$ (Chan, 2017). 2B7 levels in the assays were concentration matched assuming 925 pmol UGT2B7 per mg Supersome extract (Fallon et al., 2013). The measurements were performed in triplicate, and representative nanodisc and Supersome HPLC profiles are superposed in Fig. 5. Statistical analysis of the peak areas reveals that the nanodisc and Supersome preparations produce conjugates at nearly identical rates (1.9 \pm 0.1 and $2.1 \pm 0.1 \mu \mathrm{M} \mathrm{min}{ }^{-1}$, respectively) and that their isomer distributions are also within error $(6.2 \pm 0.1$ and $6.0 \pm 0.2$, respectively). The differences in the catalytic behavior of the two preparations are within the measurement error. 


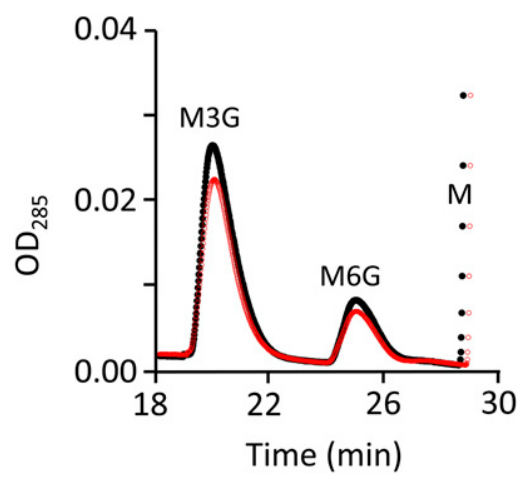

Fig. 5. Morphine glucuronides produced by nanodisc and microsomal UGT2B7. Reverse phase HPLC chromatograms of the morphine conjugates produced by the nanodisc (black dots) and microsomal (red dots) UGT2B7 are superposed. The 3- and 6-hydroxyl glucuronide peaks of morphine along with a partial peak of unconjugated morphine are labeled M3G, M6G and M, respectively. The concentrations of $2 \mathrm{~B} 7$ in the nanodisc and Supersome assays were matched (see main text). Reaction conditions: UGT2B7 nanodisc (100 nM, UGT active site) or UGT2B7 Supersomes $\left(100 \mu \mathrm{g} \mathrm{ml}^{-1}\right)$, morphine $(100 \mu \mathrm{M})$, UDPGA $(5.0 \mathrm{mM}, 21 \times$ $\mathrm{K}_{\mathrm{m}}$ ), BSA (1.0\% wt/vol, Supersomes only), alamethicin ( $25 \mathrm{nM}$, Supersomes only), saccharolactone $\left(5.0 \mu \mathrm{M}\right.$, Supersomes only), $\mathrm{MgCl}_{2}(5.0 \mathrm{mM}), \mathrm{KPO}_{4}(50 \mathrm{mM}), \mathrm{pH}$ $7.5,25 \pm 2{ }^{\circ} \mathrm{C}$. Reactions were initiated by addition of UDGPA. Less than $5 \%$ of the morphine consumed at the end point of the reaction was formed during the measurement. Reaction were quenched and chromatographically separated as described in Materials and Methods, subsection Rate Studies Using Morphine.

\section{Conclusions}

The first UGT nanodisc, the human UGT2B7•nanodisc, has been assembled, purified, and characterized. The initial-rate parameters of the UGT2B7•nanodisc faithfully reproduce those of UGT2B7 in microsomes (i.e., Supersomes); hence, the catalytic integrity of UGT2B7 is neither enhanced nor compromised by its inclusion in nanodiscs. Further, the reactivity of UGT2B7 in nanodiscs and microsomes toward morphine is virtually indistinguishable. The purity of the nanodisc allows simplification of the UGT assay, circumventing the need to parameterize assays with respect to BSA, alamethicin, and saccharolactone. Their catalytic performance, stability, purity, and simplified assay recommend nanodiscs as an attractive alternative to the longstanding microsomal systems. We anticipate that the nanodisc technology can be used to purify many if not most human UGT isoforms, and that access to pure, stable, catalytically robust UGT nanodiscs will provide unprecedented opportunities to study this disease-relevant enzyme family.

\section{Acknowledgments}

We thank the Albert Einstein Analytical Imaging Facility for electron microscopy support and Dr. Ting Wang for her assistance in the very early stages of this project.

\section{Authorship Contributions}

Participated in research design: Cook, Asenjo, Sosa, Leyh.

Conducted experiments: Cook, Asenjo.

Performed data analysis: Cook, Leyh.

Wrote or contributed to the writing of the manuscript: Cook, Leyh.

\section{References}

Andreassi JL II and Leyh TS (2004) Molecular functions of conserved aspects of the GHMP kinase family. Biochemistry 43:14594-14601

Antonio L, Xu J, Little JM, Burchell B, Magdalou J, and Radominska-Pandya A (2003) Glucuronidation of catechols by human hepatic, gastric, and intestinal microsomal UDPglucuronosyltransferases (UGT) and recombinant UGT1A6, UGT1A9, and UGT2B7. Arch Biochem Biophys 411:251-261.

Argikar UA (2018) Saccharolactone: the history, the myth, and the practice. Curr Drug Metab 19: 304-309.

Bánhegyi G, Garzó T, Fulceri R, Benedetti A, and Mandl J (1993) Latency is the major determinant of UDP-glucuronosyltransferase activity in isolated hepatocytes. FEBS Lett 328:149-152.
Barbier O, Turgeon D, Girard C, Green MD, Tephly TR, Hum DW, and Bélanger A (2000) 3'azido-3'-deoxythimidine (AZT) is glucuronidated by human UDP-glucuronosyltransferase 2B7 (UGT2B7). Drug Metab Dispos 28:497-502.

Bock KW, Eckle T, Ouzzine M, and Fournel-Gigleux S (2000) Coordinate induction by antioxidants of UDP-glucuronosyltransferase UGT1A6 and the apical conjugate export pump MRP2 (multidrug resistance protein 2) in Caco-2 cells. Biochem Pharmacol 59:467-470.

Casas-Finet JR, Wilson SH, and Karpel RL (1992) Selective photochemical modification by trichloroethanol of tryptophan residues in proteins with a high tyrosine-to-tryptophan ratio. Anal Biochem 205:27-35.

Chan KW (2017) Validation of a straightforward high performance liquid chromatographic method for morphine quantitation. Egypt J Forensic Sci 7:1.

Cheng Z, Rios GR, King CD, Coffman BL, Green MD, Mojarrabi B, Mackenzie PI, and Tephly TR (1998) Glucuronidation of catechol estrogens by expressed human UDPglucuronosyltransferases (UGTs) 1A1, 1A3, and 2B7. Toxicol Sci 45:52-57.

Chopra A, Willmore WG, and Biggar KK (2019) Protein quantification and visualization via ultraviolet-dependent labeling with 2,2,2-trichloroethanol. Sci Rep 9:13923.

Civjan NR, Bayburt TH, Schuler MA, and Sligar SG (2003) Direct solubilization of heterologously expressed membrane proteins by incorporation into nanoscale lipid bilayers. Biotechniques $\mathbf{3 5}$ : 556-560, 562-553.

Cleland WW (1979) Statistical analysis of enzyme kinetic data. Methods Enzymol 63:103-138.

Coffman BL, King CD, Rios GR, and Tephly TR (1998) The glucuronidation of opioids, other xenobiotics, and androgens by human UGT2B7Y(268) and UGT2B7H(268). Drug Metab Dispos 26:73-77.

Cook I, Wang T, and Leyh TS (2017) Tetrahydrobiopterin regulates monoamine neurotransmitter sulfonation. Proc Natl Acad Sci USA 114:E5317-E5324.

Cook I, Wang T, and Leyh TS (2019) Isoform-specific therapeutic control of sulfonation in humans. Biochem Pharmacol 159:25-31.

Court MH, Krishnaswamy S, Hao Q, Duan SX, Patten CJ, Von Moltke LL, and Greenblatt DJ (2003) Evaluation of 3'-azido-3'-deoxythymidine, morphine, and codeine as probe substrates for UDP-glucuronosyltransferase 2B7 (UGT2B7) in human liver microsomes: specificity and influence of the UGT2B7*2 polymorphism. Drug Metab Dispos 31:1125-1133.

Denisov IG, Grinkova YV, Lazarides AA, and Sligar SG (2004) Directed self-assembly of monodisperse phospholipid bilayer Nanodiscs with controlled size. J Am Chem Soc 126 $3477-3487$.

Ezure T, Suzuki T, Higashide S, Shintani E, Endo K, Kobayashi S, Shikata M, Ito M, Tanimizu K, and Nishimura $\mathrm{O}$ (2006) Cell-free protein synthesis system prepared from insect cells by freezethawing. Biotechnol Prog 22:1570-1577.

Fallon JK, Neubert H, Goosen TC, and Smith PC (2013) Targeted precise quantification of 12 human recombinant uridine-diphosphate glucuronosyl transferase 1A and $2 \mathrm{~B}$ isoforms using nano-ultra-high-performance liquid chromatography/tandem mass spectrometry with selected reaction monitoring. Drug Metab Dispos 41:2076-2080.

Fox RO Jr and Richards FM (1982) A voltage-gated ion channel model inferred from the crysta structure of alamethicin at 1.5-A resolution. Nature 300:325-330.

Francés B, Gout R, Campistron G, Panconi E, and Cros J (1990) Morphine-6-glucuronide is more mu-selective and potent in analgesic tests than morphine. Prog Clin Biol Res 328: $477-480$

Gibson DG, Young L, Chuang RY, Venter JC, Hutchison CA III, and Smith HO (2009) Enzymatic assembly of DNA molecules up to several hundred kilobases. Nat Methods 6:343-345.

Girard C, Barbier O, Veilleux G, El-Alfy M, and Bélanger A (2003) Human uridine diphosphateglucuronosyltransferase UGT2B7 conjugates mineralocorticoid and glucocorticoid metabolites. Endocrinology 144:2659-2668.

Hagn F, Etzkorn M, Raschle T, and Wagner G (2013) Optimized phospholipid bilayer nanodiscs facilitate high-resolution structure determination of membrane proteins. J Am Chem Soc 135: 1919-1925.

Hum DW, Bélanger A, Lévesque E, Barbier O, Beaulieu M, Albert C, Vallée M, Guillemette C, Tchernof A, Turgeon D, et al. (1999) Characterization of UDP-glucuronosyltransferases active on steroid hormones. J Steroid Biochem Mol Biol 69:413-423.

Jacob L, Beecken V, Bartunik LJ, Rose M, and Bartunik HD (1991) Purification and crystallization of yeast hexokinase isoenzymes. Characterization of different forms by chromatofocusing. J Chromatogr A 587:85-92.

Jedlitschky G, Cassidy AJ, Sales M, Pratt N, and Burchell B (1999) Cloning and characterization of a novel human olfactory UDP-glucuronosyltransferase. Biochem J 340:837-843.

Kumar RB, Zhu L, Hebert H, Jegerschöld C (2017) Method to Visualize and analyze membrane interacting proteins by transmission electron microscopy. J Vis $\operatorname{Exp}$ (121), e55148, doi: 10.3791/ 55148 (2017).1940-087X

Kurkela M, García-Horsman JA, Luukkanen L, Mörsky S, Taskinen J, Baumann M, Kostiainen R, Hirvonen J, and Finel M (2003) Expression and characterization of recombinant human UDPglucuronosyltransferases (UGTs). UGT1A9 is more resistant to detergent inhibition than other UGTs and was purified as an active dimeric enzyme. J Biol Chem 278:3536-3544.

Ladner CL, Edwards RA, Schriemer DC, and Turner RJ (2006) Identification of trichloroethanol visualized proteins from two-dimensional polyacrylamide gels by mass spectrometry. Anal Chem 78:2388-2396.

Lazard D, Zupko K, Poria Y, Nef P, Lazarovits J, Horn S, Khen M, and Lancet D (1991) Odorant signal termination by olfactory UDP glucuronosyl transferase. Nature 349: 790-793.

Lv X, Zhang JB, Hou J, Dou TY, Ge GB, Hu WZ, and Yang L (2019) Chemical probes for human UDP-glucuronosyltransferases: a comprehensive review. Biotechnol J 14:e1800002.

Mackenzie PI (1987) Rat liver UDP-glucuronosyltransferase. Identification of cDNAs encoding two enzymes which glucuronidate testosterone, dihydrotestosterone, and beta-estradiol. $J$ Biol Chem 262:9744-9749.

Manevski N, Moreolo PS, Yli-Kauhaluoma J, and Finel M (2011) Bovine serum albumin decreases $\mathrm{Km}$ values of human UDP-glucuronosyltransferases 1A9 and 2B7 and increases Vmax values of UGT1A9. Drug Metab Dispos 39:2117-2129.

Mannervik B (1985) The isoenzymes of glutathione transferase. Adv Enzymol Relat Areas Mol Biol 57:357-417.

Meech R, Hu DG, McKinnon RA, Mubarokah SN, Haines AZ, Nair PC, Rowland A, and Mackenzie PI (2019) The UDP-glycosyltransferase (UGT) superfamily: new members, new functions, and novel paradigms. Physiol Rev 99:1153-1222.

Meech R and Mackenzie PI (1997) UDP-glucuronosyltransferase, the role of the amino terminus in dimerization. J Biol Chem 272:26913-26917. 
Meech R and Mackenzie PI (1998) Determinants of UDP glucuronosyltransferase membrane association and residency in the endoplasmic reticulum. Arch Biochem Biophys 356:77-85.

Meijerman I, Beijnen JH, and Schellens JH (2008) Combined action and regulation of phase Il enzymes and multidrug resistance proteins in multidrug resistance in cancer. Cancer Treat Rev 34:505-520.

Oda S, Fukami T, Yokoi T, and Nakajima M (2015) A comprehensive review of UDPglucuronosyltransferase and esterases for drug development. Drug Metab Pharmacokinet 30: $30-51$.

Osborne R, Joel S, Trew D, and Slevin M (1990) Morphine and metabolite behavior after different routes of morphine administration: demonstration of the importance of the active metabolite morphine-6-glucuronide. Clin Pharmacol Ther 47:12-19.

Ouzzine M, Magdalou J, Burchell B, and Fournel-Gigleux S (1999) An internal signal sequence mediates the targeting and retention of the human UDP-glucuronosyltransferase $1 \mathrm{~A} 6$ to the endoplasmic reticulum. J Biol Chem 274:31401-31409.

Pasternak GW, Bodnar RJ, Clark JA, and Inturrisi CE (1987) Morphine-6-glucuronide, a potent mu agonist. Life Sci 41:2845-2849.

Peters WH, Jansen PL, and Nauta H (1984) The molecular weights of UDP-glucuronyltransferase determined with radiation-inactivation analysis. A molecular model of bilirubin UDPglucuronyltransferase. J Biol Chem 259:11701-11705.

Radchenko MV, Thornton J, and Merrick M (2010) Control of AmtB-GlnK complex formation by intracellular levels of ATP, ADP, and 2-oxoglutarate. J Biol Chem 285:31037-31045

Richardson TA and Klaassen CD (2010) Role of UDP-glucuronosyltransferase (UGT) 2 B2 in metabolism of triiodothyronine: effect of microsomal enzyme inducers in Sprague Dawley and UGT2B2-deficient Fischer 344 rats. Toxicol Sci 116:413-421.

Robinson D, Halperin N, and Nevo Z (1991) Long-term follow-up of the fate of xenogeneic transplants of chondrocytes implanted into joint surfaces. Transplantation 52:380-383.

Rowland A, Gaganis P, Elliot DJ, Mackenzie PI, Knights KM, and Miners JO (2007) Binding of inhibitory fatty acids is responsible for the enhancement of UDP-glucuronosyltransferase 2B7 activity by albumin: implications for in vitro-in vivo extrapolation. $J$ Pharmacol Exp Ther 321: 137-147.

Rowland A, Knights KM, Mackenzie PI, and Miners JO (2008) The "albumin effect" and drug glucuronidation: bovine serum albumin and fatty acid-free human serum albumin enhance the glucuronidation of UDP-glucuronosyltransferase (UGT) 1A9 substrates but not UGT1A1 and UGT1A6 activities. Drug Metab Dispos 36:1056-1062.

Rowland A, Miners JO, and Mackenzie PI (2013) The UDP-glucuronosyltransferases: their role in drug metabolism and detoxification. Int J Biochem Cell Biol 45:1121-1132.

Sneitz N, Court MH, Zhang X, Laajanen K, Yee KK, Dalton P, Ding X, and Finel M (2009) Human UDP-glucuronosyltransferase UGT2A2: cDNA construction, expression, and functional characterization in comparison with UGT2A1 and UGT2A3. Pharmacogenet Genomics 19 923-934.

Sten T, Bichlmaier I, Kuuranne T, Leinonen A, Yli-Kauhaluoma J, and Finel M (2009) UDPglucuronosyltransferases (UGTs) 2B7 and UGT2B17 display converse specificity in testosterone and epitestosterone glucuronidation, whereas UGT2A1 conjugates both androgens similarly. Drug Metab Dispos 37:417-423.

Stone AN, Mackenzie PI, Galetin A, Houston JB, and Miners JO (2003) Isoform selectivity and kinetics of morphine 3- and 6-glucuronidation by human udp-glucuronosyltransferases: evidence for atypical glucuronidation kinetics by UGT2B7. Drug Metab Dispos 31:1086-1089.
Suominen T, Uutela P, Ketola RA, Bergquist J, Hillered L, Finel M, Zhang H, Laakso A, and Kostiainen R (2013) Determination of serotonin and dopamine metabolites in human brain microdialysis and cerebrospinal fluid samples by UPLC-MS/MS: discovery of intact glucuronide and sulfate conjugates. PLoS One 8:e68007.

Tan D, Asenjo AB, Mennella V, Sharp DJ, and Sosa H (2006) Kinesin-13s form rings around microtubules. J Cell Biol 175:25-31.

Tolson AH and Wang H (2010) Regulation of drug-metabolizing enzymes by xenobiotic receptors: PXR and CAR. Adv Drug Deliv Rev 62:1238-1249.

Uchaipichat V, Mackenzie PI, Guo XH, Gardner-Stephen D, Galetin A, Houston JB, and Miners JO (2004) Human udp-glucuronosyltransferases: isoform selectivity and kinetics of 4 methylumbelliferone and 1-naphthol glucuronidation, effects of organic solvents, and inhibition by diclofenac and probenecid. Drug Metab Dispos 32:413-423.

Vessey DA and Kempner ES (1989) In situ structural analysis of microsomal UDPglucuronyltransferases by radiation inactivation. J Biol Chem 264:6334-6338.

Visser TJ, Kaptein E, Gijzel AL, de Herder WW, Ebner T, and Burchell B (1993) Glucuronidation of thyroid hormone by human bilirubin and phenol UDP-glucuronyltransferase isoenzymes. FEBS Lett 324:358-360.

Wang T, Cook I, Falany CN, and Leyh TS (2014) Paradigms of sulfotransferase catalysis: the mechanism of SULT2A1. J Biol Chem 289:26474-26480.

Wang T, Cook I, and Leyh TS (2016) Design and interpretation of human sulfotransferase 1A1 assays. Drug Metab Dispos 44:481-484.

Wu D, Kang YS, Bickel U, and Pardridge WM (1997) Blood-brain barrier permeability to morphine6-glucuronide is markedly reduced compared with morphine. Drug Metab Dispos 25:768-771.

Yoshino M and Murakami K (2015) Analysis of the substrate inhibition of complete and partial types. Springerplus 4:292.

Yuan L, Qian S, Xiao Y, Sun H, and Zeng S (2015) Homo- and hetero-dimerization of human UDP-glucuronosyltransferase 2B7 (UGT2B7) wild type and its allelic variants affect zidovudine glucuronidation activity. Biochem Pharmacol 95:58-70.

Zelcer N, van de Wetering K, Hillebrand M, Sarton E, Kuil A, Wielinga PR, Tephly T, Dahan A, Beijnen $\mathrm{JH}$, and Borst $\mathrm{P}$ (2005) Mice lacking multidrug resistance protein 3 show altered morphine pharmacokinetics and morphine-6-glucuronide antinociception. Proc Natl Acad Sci USA 102:7274-7279.

Zhang H, Varlamova O, Vargas FM, Falany CN, and Leyh TS (1998) Sulfuryl transfer: the catalytic mechanism of human estrogen sulfotransferase [published correction appears in $J$ Biol Chem (1998) 273:17296]. J Biol Chem 273:10888-10892.

Zhang Y, Taiming L, and Liu J (2003) Low temperature and glucose enhanced T7 RNA polymerase-based plasmid stability for increasing expression of glucagon-like peptide-2 in Escherichia coli. Protein Expr Purif 29:132-139.

Zhou J and Miners JO (2014) Enzyme kinetics of uridine diphosphate glucuronosyltransferases (UGTs). Methods Mol Biol 1113:203-228.

Address correspondence to: Thomas S. Leyh, The Department Microbiology and Immunology, Albert Einstein College of Medicine, 1300 Morris Park Ave., Bronx, NY 10461-1926. E-mail: tom.leyh@einstein.yu.edu 